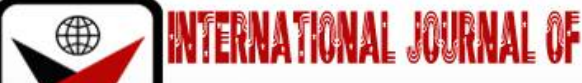

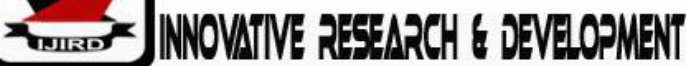

ISSN 2278-0211 (Online)

\section{Growth Performance of African Catfish (Clarius Gariepinus) Fingerlings Fed on Different Diets of Daphnias as Live Fish Feed}

\author{
John Ndirangu Kiunga \\ Ministry, Department of Agriculture and Natural Resources, \\ Kenya Methodist University, Kenya
}

\begin{abstract}
:
The production of fingerlings depend on better feeding using organic materials, farm waste from other enterprises can become converted to higher value inputs to nearby fish ponds. Catfish feed on zooplanktons (daphnia) and other hydrobios. Fertilization of these ponds using organic waste proliferate the growth of these zooplanktons and raise the yields of fish ponds. A culture of water fleas (daphnias) was used to provide live fish feed for the fingerlings. Different farm manure: biogas effluent, chicken waste and pig manure came up with the best manure to use for the growth of clarius gariepinus fingerlings. Daphnias were raised on dug out ponds, which were fertilized using biogas effluents, chicken manure and pig manure differently. Fertilization of these ponds was done at an interval of seven days.

Water fleas (Daphnia) were then harvested using $100 \mu \mathrm{m}$ zooplankton net at density 200/ml. The organisms were rinsed on a submerged filter in clean water consisting of 2 filter screens. The upper mesh size $(200 \mu \mathrm{m})$ retained large waste particles, while the lower sieve $(100 \mu \mathrm{m})$ collected the washed organisms. Feeding of the fingerlings was done three times/day (treatment at 3\% body weight while all the live feed was washed clean with water and fed to the fish fry to satiation not less than 100 live organism/fry/meal. Percentage weight gain of C. gariepinus fry within the period of the experiment was calculated. The initial weight of the fish at the commencement of the experiment and final weight was determined using Metler weighing balance (model P168). Biweekly weight measurements were taken to monitor weight gain. The Specific Growth Rate (SGR), survival and mortality rates and Feed Conversion Ratio (FCR) were also calculated. Data was analysed as per the results got. The study found that chicken manure was the best manure based on the outcome of both the weight and the length of the fingerings, Specific Growth Rate and Feed Conversion Ration. Pig manure came in second, while cow manure performed poorly. The study thus recommends the use of chicken manure in rearing Clarius gariepinus. Specific growth rate, mortality and survival rate and feed conversion rate was calculated using specific formulas, chicken manure was the best as per the findings followed by pig and cow respectively.
\end{abstract}

Keywords: Feed, catfish, daphnia, fingerlings, feed conversion ratio

\section{Introduction}

The African catfish are generally valued as among the highest quality freshwater fish in Kenya. Despite the culturable characteristic of clarid species, their availability is limited due to inadequate hatchery system and insufficient live food of good quality and quantity for the juveniles. This therefore constitutes to be a major problem to fish farmers and hatchery owners. The problem of inadequate fingerlings supply is due to the fact that most hatchery operations rely on dacapsolated Artemia, which is very expensive and scarce because it is imported into the country to feed fry, particularly Clarias. However, the mass culture of live food requires considerable space and capital due to energy, equipment and manpower (Won et. al., 2016). The production of fingerlings depends on better feeding using organic materials, farm waste from other enterprises can become converted to higher value inputs to nearby fish ponds. Catfish feed on zooplanktons (daphnia) and other hydrobios. Fertilization of these ponds using organic waste proliferate the growth of these zooplanktons and raise the yields of fish ponds. A culture of water fleas (daphnias) provides live fish feed for the fingerlings. Different farm manure: biogas effluent, chicken waste and pig manure are commonly available for use for the growth of clarius gariepinus fingerlings. Freshwater cat fish fry survive on freshwater zooplankton in the wild without the use of shell free artemia, or artemia nauplii. This implies that freshwater fish fry does survive on freshwater zooplankton. Most hatcheries depend only on artemia shell free for feeding of fry during the early stage of development. Sometimes artemia is not available and if available may not be in enough quantity, or may be found only in the cities where the local farmers rarely get access to them. Oftentimes, the artemia shell free (artificial feed) develops waste materials that pollute the water of fry culture. Owing to this limitation, farmers to depend on fingerlings produced in the wild for culture and fish production. This research journal therefore is an attempt to overcome these problems through establishing 
different cultures of water fleas (Daphnia) fed from different farm yard manure as live fish feed for the production of African Catfish (Clarius Gariepinus) Fingerlings.

\section{Methods}

The experiment was conducted at the Kenya Fisheries Hatchery in Meru County.

\subsection{Experimental Diet}

The experimental diets were applied to the African Catfish (Clarius Gariepinus) Fingerlings, by feeding them with live water fleas (Daphnia). Feeding of the diet were applied at 3\% feeding rates, giving three feeding arrangements. The test diet was fed to duplicate groups for 8 weeks. The feed/experimental diet was analysed for proximate composition according to A.O.A.C (2019).

\subsection{Experimental Fish}

The fingerlings used in this study were three-day old newly hatched C. gariepinus fry after yolk absorption. The initial weight and standard length of the fingerlings were measured using JT $210 \mathrm{~N}$ series electronic top loading balance of two digits and a plastic ruler (cm), respectively. This was done by quickly taking the fingerlings out of water with the aid of a linen cloth and transferring them into a pre-weighed container using feather and then weighed on the balance. The length $(\mathrm{mm})$ was taken by collecting some fry from the container and a plastic ruler was used to measure the reading. One hundred and fifty fingerlings of Clarias gariepinus were obtained from Kenya Fisheries Hatchery Nairobi. The fingerlings were transported to the Fisheries Laboratory in 50 litres plastic bowls and acclimatized for one week. During the period of acclimatization, the fingerlings were fed ad libitum (Ngugi, et al 2017) at 5\% body weight twice daily (Manyala, et al, 2015) with a formulated diet of $35 \%$ crude protein. Feed not consumed and faecal matters were siphoned out every two days interval. At the end of the acclimatization period, the fingerlings were randomly selected and stocked into 12 glass aquaria with each aquarium holding 10 fingerlings. Feeding was suspended 24 hours before the feeding trial to increase appetite and reception for new diet (Ngugi, et al 2017).

\subsection{Experimental Design}

Live water fleas (Daphnia) as diet which was fed at 3\% fry body weight, constituted the three treatments of the experiment and control group, whereby each treatment was replicated three times in a Completely Randomized Design (CRD), making up twelve experimental units. 30 litre capacity plastic bowls were used for the feeding experiment.

\subsection{Experimental Set-Up and Management}

Each of the plastic bowls was filled to 25litre mark with reserved water and stocked with 10 fingerlings of three days old. The bowls were supplied with oxygen from aerator. Feeding was thrice daily, in the morning (7:00-8:00am), afternoon (1:00-2:00pm), and evening (6:00-7:00pm). The control group was fed using Multifeed, a commercial complete dry catfish food, manufactured by Zemach Feed Mill, Jordan Valley, and (Israel). The feed was fed to the fry at 3\% body weight in accordance to the experimental set up in the experiment of water fleas (Daphnia). Remains of the feed were siphoned out of the culture medium before feeding and same quantity of water removed during siphoning was replaced immediately. Total renewal of whole water was done every three days, and the bowls bottoms were scrubbed to remove dirt from the medium. The experiment lasted for eight weeks.

\subsection{Growth and Mortality Monitoring}

The survival and mortality rates were monitored on daily basis. The weight and the total length of the fry were taken at intervals of 7 days.

\subsection{Water Quality Analysis}

Two water quality parameters ( $\mathrm{pH}$ and temperature) were taken daily in the morning, afternoon and evening. These parameters were read for each of the experimental units. Temperature was recorded with the aid of mercury in glass thermometer which ranges from 00C to 1000 degrees centigrade, calibrated at an interval of 10 degrees centigrade. The thermometer was immersed into the water in each of the culture tanks for a period of time sufficient to permit complete equilibration, and the mercury level was observed as water temperature. The $\mathrm{pH}$ was determined with the aid of a pH meter (Jenway 2016, Model).

\subsection{Experimental Procedure}

The temperature $\left({ }^{\circ} \mathrm{C}\right), \mathrm{pH}$ (Hydrogen ion concentration) Alkalinity (mgL-1), Free Carbon oxide (mg/L) and Dissolved Oxygen (mL-1) in water used for each treatment in the aquaria was monitored on weekly basis by collecting in depth of $2 \mathrm{~cm}$ below the water surface. The methods of APHA/AWWA/WPCF (2015) were employed. Water fleas (Daphnia) were then harvested using $100 \mu \mathrm{m}$ zooplankton net at density $200 / \mathrm{ml}$. The organisms were rinsed on a submerged filter in clean water consisting of 2 filter screens. The upper mesh size $(200 \mu \mathrm{m})$ retained large waste particles, while the lower sieve $(100 \mu \mathrm{m})$ collected the washed organisms. Feeding was done three times/day (treatment at $3 \%$ body weight while all the live feed was washed clean with water and fed to the fish fry to satiation not less than 100 live organism/fry/meal (Manyala,et al, 2015).

Percentage weight gain of C. gariepinus fry within the period of the experiment was calculated (Engle, et al, 2016). Percentage weight gain $(\mathrm{PWG})=100(\mathrm{~W} 2-\mathrm{W} 1 / \mathrm{W} 1)$. Where W2 = final mean body weight and W1 = initial mean body 
weight. Total body length of the fry was measured in centimetre. The fry was placed with water into transparent glass to determine the total length with measuring tape/ruler (Ngugi, et al 2015). The condition of the fry was calculated according to (Hien, et al 2016). Condition factor $(\mathrm{K})=100 \mathrm{w} / \mathrm{L} 3$. Where $\mathrm{w}=$ weight of fish in $(\mathrm{g}), \mathrm{L}=$ length of fish in $(\mathrm{cm})$. The percentage of survival of the fry within the duration of the experiment was calculated (Hien, et al 2017). Percentage survival rate $=100$ (No. of fry that survived / Total No. of fry that start the treatment in each aquarium). The initial weight of the fish at the commencement of the experiment and final weight was determined using Metler weighing balance (model P168). Biweekly weight measurements were taken to monitor weight gain. The Specific Growth Rate (SGR) was calculated as described by Ngugi et al (2015)

$\mathrm{SGR}=$ (Ln (final weight in grams)-Ln (initial weight in grams) $\times 100$ )

$\mathrm{t}$

Where W1 = Initial body weight

W2 $=$ Final body weight

$\mathrm{t}=$ time (days)

Survival and mortality rates were calculated using the formula:

i. Survival Rate $(\%)=$ Number of Fish at the End of the Experiment

X 100

Number of Fish at the beginning of the Experiment

ii. Mortality rate $(\%)=$ Number of Fish that died during the experiment $\quad X 100$

Number of Fish at the beginning of the Experiment

(Ngugi et al, 2017)

Feed conversion ratio was also calculated using the formula

FCR=Feed given/Animal weight gain (Ngugi et al, 2016)

\subsection{Data Analysis}

Mean values of the water quality parameters measured were calculated. Mean values of weight measurements were subjected to Analysis of variance (ANOVA) and tested for significance difference at $\mathrm{P}=0.05(5 \%$ probability level). Computer analysis was carried out using the SPSS Version: 26.0 package for windows.

\section{Results}

\subsection{One-Way Analysis of Variance for Weight Measurements}

To compare the difference of the implication of each of the three ponds with respect to the control pond, a OneWay Analysis of Variance was used. This approach was considered due to the tendency of the t-statistic to cumulate the type one error where a test is repeated severally. In this regard, given that the comparison was required between more than two variables, namely; the control pond, the chicken manure pond, the cow manure pond, and the pig manure pond, a one-way ANOVA and Tukey post-hoc tests were conducted. This was done to facilitate in the determination of whether there were significance differences in the variations while facilitating in ranking the suitability of each of the manure. These tests were done for the data collected on both weight and length. For purposes of this study the data from the control pond was used as the dependent variable while the other ponds provided data for the independent variables. The resultant results in this case are discussed below.

\subsection{Descriptive Statistics}

In determining how weight of the Clarius Gariepinus varied in the various ponds, the study first sought to find out the descriptive statistics for the data collected in this regard. The information of interest in this case included the mean, the standard deviation, and 95\% confidence levels for the dependent variable (Control pond) and for each of the separate ponds (pig manure, chicken manure, and cow manure) as well as for all the groups combined (total). The results in this regard are presented in the table below.

\begin{tabular}{|c|c|c|c|c|c|c|c|c|}
\hline \multicolumn{9}{|c|}{ Descriptive } \\
\hline & N & Mean & $\begin{array}{c}\text { Std. } \\
\text { Deviation }\end{array}$ & $\begin{array}{c}\text { Std. } \\
\text { Error }\end{array}$ & $\begin{array}{c}\text { 95\% Confidence } \\
\text { Interval for Mean }\end{array}$ & Minimum & Maximum \\
\cline { 5 - 9 } & & & & $\begin{array}{c}\text { Lower } \\
\text { Bound }\end{array}$ & $\begin{array}{c}\text { Upper } \\
\text { Bound }\end{array}$ & \\
\hline Control & 9 & 34.3630 & 15.16286 & 5.05429 & 22.7078 & 46.0182 & 13.00 & 57.90 \\
\hline Chicken & 9 & 45.9059 & 23.94693 & 7.98231 & 27.4987 & 64.3132 & 13.00 & 82.35 \\
\hline Pig & 9 & 34.9815 & 16.74691 & 5.58230 & 22.1087 & 47.8543 & 12.33 & 59.47 \\
\hline Cow & 9 & 33.8870 & 16.12585 & 5.37528 & 21.4916 & 46.2825 & 11.33 & 58.12 \\
\hline Total & 36 & 37.2844 & 18.24309 & 3.04051 & 31.1118 & 43.4569 & 11.33 & 82.35 \\
\hline
\end{tabular}

Table 1: Descriptive Statistics

The findings show that the chicken manure pond yielded the highest mean weight of 45.9059 while the pig manure pond followed with 34.9815. The cow manure pond trailed with 33.8870. 


\subsection{ANOVA}

Similarly, an analysis of variance for all the ponds (total) with respect to weight was also determined. This was done to determine whether there exists a statistically significant difference between the group means. The results in this regard are presented in the table below.

\begin{tabular}{|c|c|c|c|c|c|}
\hline \multicolumn{6}{|c|}{ ANOVA } \\
\hline & $\begin{array}{c}\text { Weight } \\
\text { Squares }\end{array}$ & $\mathrm{df}$ & $\begin{array}{c}\text { Mean } \\
\text { Square }\end{array}$ & $\mathrm{F}$ & Sig. \\
\hline $\begin{array}{c}\text { Between } \\
\text { Groups }\end{array}$ & 897.399 & 3 & 299.133 & .890 & .457 \\
\hline Within Groups & 10750.959 & 32 & 335.967 & & \\
\hline Total & 11648.358 & 35 & & & \\
\hline \multicolumn{7}{|c|}{ Table 2: ANOVA }
\end{tabular}

As it can be seen from the table above the level of significance is $0.457(p=0.457)$, which is greater than 0.05 , and thus, it follows that there is a statistically insignificant difference in the mean weight of the fingerlings from the various ponds used in the study. This information is general and does not shed light on how the manure ponds compared amongst each other. In this regard, the study went further and adopted post-hoc tests to clearly provide this information.

\subsection{Post hoc Tests}

The post-hoc tests yielded a multiple comparisons table which provided further information and analysis on the data collected. The information provided was able to clearly show how the manure ponds differed with each other to facilitate in ranking. For purposes of this, the Tukey post-hoc test was preferred in carrying out the post-hoc tests on a one-way ANOVA. The findings in this regard are presented in the table below.

\begin{tabular}{|c|c|c|c|c|c|c|}
\hline \multicolumn{7}{|c|}{ Multiple Comparisons } \\
\hline \multicolumn{7}{|c|}{ Tukey HSD } \\
\hline \multirow{3}{*}{ (I) Pond } & J) Pond & $\begin{array}{c}\text { Mean } \\
\text { Difference } \\
\text { (I-J) }\end{array}$ & $\begin{array}{c}\text { Std. } \\
\text { Error }\end{array}$ & \multirow{2}{*}{ Sig. } & \multicolumn{2}{|c|}{$95 \%$ Confidence Interval } \\
\cline { 3 - 7 } & & & & $\begin{array}{c}\text { Lower } \\
\text { Bound }\end{array}$ & $\begin{array}{c}\text { Upper } \\
\text { Bound }\end{array}$ \\
\hline \multirow{3}{*}{ Control } & Chicken & -11.54296 & 8.64057 & .548 & -34.9534 & 11.8675 \\
\cline { 2 - 7 } & Pig & -.61852 & 8.64057 & 1.000 & -24.0289 & 22.7919 \\
\cline { 2 - 7 } & Cow & .47593 & 8.64057 & 1.000 & -22.9345 & 23.8864 \\
\hline Chicken & Control & 11.54296 & 8.64057 & .548 & -11.8675 & 34.9534 \\
\cline { 2 - 7 } & Pig & 10.92444 & 8.64057 & .592 & -12.4860 & 34.3349 \\
\cline { 2 - 7 } & Cow & 12.01889 & 8.64057 & .514 & -11.3915 & 35.4293 \\
\hline \multirow{3}{*}{ Pig } & Control & .61852 & 8.64057 & 1.000 & -22.7919 & 24.0289 \\
\cline { 2 - 7 } & Chicken & -10.92444 & 8.64057 & .592 & -34.3349 & 12.4860 \\
\cline { 2 - 7 } & Cow & 1.09444 & 8.64057 & .999 & -22.3160 & 24.5049 \\
\hline \multirow{3}{*}{ Cow } & Control & -.47593 & 8.64057 & 1.000 & -23.8864 & 22.9345 \\
\cline { 2 - 7 } & Chicken & -12.01889 & 8.64057 & .514 & -35.4293 & 11.3915 \\
\cline { 2 - 7 } & Pig & -1.09444 & 8.64057 & .999 & -24.5049 & 22.3160 \\
\hline
\end{tabular}

Table 3: Post-hoc Tests

The findings in the table above show that there is insignificant difference in growth of the fingerings between the control pond, and the pig manure pond $(p=1.00)$, the cow manure pond $(p=1.00)$, and the chicken manure pond $(p=0.548)$ all of which are greater than the 0.05 level of significance used in the study. These results are true for the three independent variables in comparison to each other as shown by the higher level of significance over and above the level of 0.05 used in the study. However, the magnitude of deviation of the significance level from the 0.05 used in the study was used in ranking the growth levels of the fingerlings based on the weight increment under the various conditions. The study in this case first used a comparison of each of the manure ponds with control pond. In this case chicken manure pond was found to have the least variation $(p=0.548)$ while the other independent variables had $p$-value of $1.00(p=1.00)$. In this case, chicken manure pond was ranked first and used to assess the other two variables. A comparison of the pig manure, and the cow manure against the chicken manure showed that the cow manure had the least deviation $(\mathrm{p}=.514)$ against that of the pig manure $(\mathrm{p}=0.592)$. It therefore follows that the cow manure pond ranks second, while the pig manure trails.

\subsection{Homogeneous Subsets}

The check of homogeneous subsets was used to ascertain the results obtained from the multiple comparison tables above as well as the inferences arrived under the post-hoc tests. The homogenous subsets were used to check whether the manure ponds fell in the same category in terms of significance to each other. The findings in this regard are shown in the table below. 


\begin{tabular}{|c|c|c|}
\hline \multicolumn{3}{|c|}{ Weight } \\
\hline \multicolumn{3}{|c|}{ Tukey HSD } \\
\cline { 2 - 3 } & $\mathrm{N}$ & Subset for alpha $=0.05$ \\
\hline Pond & 9 & 1 \\
\hline Control & 9 & 33.8870 \\
\hline Pig & 9 & 34.3630 \\
\hline Chicken & 9 & 34.9815 \\
\hline Sig. & & 45.9059 \\
\hline Means for groups in homogeneous subsets are displayed. \\
\hline \multicolumn{2}{|c|}{ a. Uses Harmonic Mean Sample Size = 9.000. } \\
\hline \multicolumn{3}{|c|}{ Table 4: Homogeneous Subsets }
\end{tabular}

The findings in this case showed that all the variables fall in the same group (group 1). This supports our findings above that all the variables had insignificant differences with each other. Moreover, the findings support the inferences arrived at under the post-hoc tests conducted above. As seen in the table above, the mean figures obtained under the group 1 figures showed that the chicken pond has the highest figure of 45.9 .

\subsection{One-Way Analysis of Variance for Length Measurements}

Similarly, the study sought to contrast the above findings on weight of fingerlings against the respective length. The analysis in this regard also entailed an assessment of the descriptive statistics, an ANOVA and a test for homogenous subsets. The findings in this regard are discussed below.

\subsection{Descriptive Statistics}

In determining how length of the Clarius Gariepinus varied in the various ponds, the study first sought to find out the descriptive statistics for the data collected in this regard. The information of interest in this case included the mean, the standard deviation, and 95\% confidence levels for the dependent variable (Control pond) and for each of the separate ponds (pig manure, chicken manure, and cow manure) as well as for all the groups combined (total). The results in this regard are presented in the table below.

\begin{tabular}{|c|c|c|c|c|c|c|c|c|}
\hline \multicolumn{9}{|c|}{ Descriptive } \\
\hline \multicolumn{9}{|c|}{ Length } \\
\hline & \multirow[t]{2}{*}{$\mathrm{N}$} & \multirow[t]{2}{*}{ Mean } & \multirow[t]{2}{*}{$\begin{array}{c}\text { Std. } \\
\text { Deviation }\end{array}$} & \multirow[t]{2}{*}{$\begin{array}{l}\text { Std. } \\
\text { Error }\end{array}$} & \multicolumn{2}{|c|}{$\begin{array}{l}\text { 95\% Confidence } \\
\text { Interval for Mean }\end{array}$} & \multirow[t]{2}{*}{ Minimum } & \multirow[t]{2}{*}{ Maximum } \\
\hline & & & & & $\begin{array}{l}\text { Lower } \\
\text { Bound }\end{array}$ & $\begin{array}{l}\text { Upper } \\
\text { Bound }\end{array}$ & & \\
\hline Control & 9 & 2.5378 & .71230 & .23743 & 1.9903 & 3.0853 & 1.58 & 3.67 \\
\hline Chicken & 9 & 3.5389 & 1.42461 & .47487 & 2.4438 & 4.6339 & 1.63 & 5.81 \\
\hline Pig & 9 & 3.0211 & 1.06747 & .35582 & 2.2006 & 3.8416 & 1.55 & 4.68 \\
\hline Cow & 9 & 2.2474 & .57653 & .19218 & 1.8042 & 2.6906 & 1.49 & 3.18 \\
\hline Total & 36 & 2.8363 & 1.07893 & .17982 & 2.4712 & 3.2014 & 1.49 & 5.81 \\
\hline
\end{tabular}

Table 5: Descriptive Statistics

\subsection{ANOVA}

Similarly, an analysis of variance for all the ponds with respect to the length of the fingerlings in centimetres was also determined. This was done to determine whether there exists a statistically significant difference between the group means. The results in this regard are presented in the table below.

\begin{tabular}{|c|c|c|c|c|c|}
\hline \multicolumn{7}{|c|}{ ANOVA } \\
\hline \multicolumn{7}{|c|}{ Length } \\
\hline & Sum of Squares & Df & Mean Square & F & Sig. \\
\hline Between Groups & 8.673 & 3 & 2.891 & 2.885 & .051 \\
\hline Within Groups & 32.070 & 32 & 1.002 & & \\
\hline Total & 40.743 & 35 & & & \\
\hline
\end{tabular}

Table 6: ANOVA

As it can be seen from the table above the level of significance is $0.051(p=0.051)$, which is slightly greater than 0.05 , and thus, it follows that there is a statistically insignificant difference in the mean length of the fingerlings as measured in centimetres from the various ponds used in the study. This information is general and vague on how the manure ponds compared amongst each other. In this regard, the study went further and adopted post-hoc tests to clearly provide this information. 


\subsection{Post Hoc Tests on the Length Measured from Each Manure Pond}

The post-hoc tests with regard to length of the fingerlings yielded a multiple comparisons table which provided further information and analysis on the data collected. The information provided was able to clearly show how the manure ponds differed with each other to facilitate in ranking. For purposes of this the Tukey post-hoc test was preferred in carrying out the post-hoc tests on a one-way ANOVA. The findings in this regard are presented in Table 7.

\begin{tabular}{|c|c|c|c|c|c|c|}
\hline \multicolumn{7}{|c|}{ Multiple Comparisons } \\
\hline \multicolumn{7}{|c|}{ Dependent Variable: Length } \\
\hline \multicolumn{7}{|c|}{ Tukey HSD } \\
\hline \multirow[t]{2}{*}{ (I) Pond } & \multirow[t]{2}{*}{ (J) Pond } & \multirow{2}{*}{$\begin{array}{c}\text { Mean } \\
\text { Difference (I-J) }\end{array}$} & \multirow[t]{2}{*}{ Std. Error } & \multirow[t]{2}{*}{ Sig. } & \multicolumn{2}{|c|}{ 95\% Confidence Interval } \\
\hline & & & & & Lower Bound & Upper Bound \\
\hline \multirow[t]{3}{*}{ Control } & Chicken & -1.00111 & .47192 & .168 & -2.2797 & .2775 \\
\hline & Pig & -.48333 & .47192 & .737 & -1.7619 & .7953 \\
\hline & Cow & .29037 & .47192 & .926 & -.9882 & 1.5690 \\
\hline \multirow[t]{3}{*}{ Chicken } & Control & 1.00111 & .47192 & .168 & -.2775 & 2.2797 \\
\hline & Pig & .51778 & .47192 & .694 & -.7608 & 1.7964 \\
\hline & Cow & $1.29148^{*}$ & .47192 & .047 & .0129 & 2.5701 \\
\hline \multirow[t]{3}{*}{ Pig } & Control & .48333 & .47192 & .737 & -.7953 & 1.7619 \\
\hline & Chicken & -.51778 & .47192 & .694 & -1.7964 & .7608 \\
\hline & Cow & .77370 & .47192 & .372 & -.5049 & 2.0523 \\
\hline \multirow[t]{3}{*}{ Cow } & Control & -.29037 & .47192 & .926 & -1.5690 & .9882 \\
\hline & Chicken & $-1.29148^{*}$ & .47192 & .047 & -2.5701 & -.0129 \\
\hline & Pig & -.77370 & .47192 & .372 & -2.0523 & .5049 \\
\hline
\end{tabular}

Table 7: Post Hoc Tests

The findings in the table above show that there is insignificant difference in growth of the fingerings between the control pond, and the pig manure pond ( $p=0.737)$, the cow manure pond $(p=0.926)$, and the chicken manure pond $(p=0.168)$ all of which are greater than the 0.05 level of significance used in the study. These results are true for the comparison between chicken manure pond against the pig manure pond as shown by the higher level of significance $(p=0.694)$ over and above the level of 0.05 used in the study. However, a comparison between the chicken manure pond and the cow manure pond revealed a significance difference in length of fingerlings as shown by the significance level of $0.047(\mathrm{p}=0.047)$ which is lower than the 0.05 level of significance used in the study. This is supported by the significant difference obtained between the two ponds when comparing the significance differences with the control pond of 0.168 for chicken manure pond against 0.926 of the cow manure ponds. Based on the scale of deviation of the significance level from the 0.05 used in the study the cow manure pond was found to have the greatest variation $(p=0.926)$ thus ranking it last. On the other hand, the chicken manure pond was found to have the least variance $(p=0.168)$ thus ranking as the best manure pond. These views contrast with the findings on weigh positively. To affirm these findings the study further considered the output of a test of homogeneous subsets of the four ponds under consideration. The findings in this regard are discussed below.

\subsection{Homogeneous Subsets on Length of Fingerlings}

The check of homogeneous subsets was used to ascertain the results obtained from the multiple comparison tables above as well as the inferences arrived under the post-hoc tests. The homogenous subsets were used to check whether the manure ponds fell in the same category in terms of significance to each other. The findings in this regard are shown in the table below.

\begin{tabular}{|c|c|c|c|}
\hline \multicolumn{4}{|c|}{ Length } \\
\hline \multicolumn{3}{|c|}{ Tukey HSD } \\
\hline Pond & $\mathrm{N}$ & 1 & Subset for alpha $=0.05$ \\
\cline { 2 - 4 } & 9 & 2.2474 & 2 \\
\hline Cow & 9 & 2.5378 & 2.5378 \\
\hline Control & 9 & 3.0211 & 3.0211 \\
\hline Pig & 9 & .372 & .168 \\
\hline Chicken & \multicolumn{3}{c|}{} \\
\hline Sig. & Means for groups in homogeneous subsets are displayed. \\
\hline \multicolumn{4}{|c|}{ a. Uses Harmonic Mean Sample Size $=9.000}$. \\
\hline
\end{tabular}

The findings in this case show that all the variables fall in two groups, that is group 1 and group 2 . Group 1 has the cow manure pond and the pig manure pond. This implies that there is insignificance difference between these ponds. On 
the other hand, group 2 has the pig manure pond. Similarly, this implies that there is no significant difference between these manure ponds. However, the cow manure pond and the chicken manure pond fall in different groups implying that there exists a significance difference between lengths obtained from these ponds. Consequently, based on the mean figures obtained in the table, it is evident that the chicken manure pond has the highest mean (3.53) followed by the pig manure pond with a mean of 3.02, while the cow manure pond trails with a low mean of 2.24 .

\subsection{Means Plot}

Subsequently, the study sought to support the inferences made through the use of visual aid. A graph was adopted to give a clear visual impression of the rankings of the three ponds. In this regard a means plot was obtained from the SPSS analysis. The findings in this case are presented in the figure below.

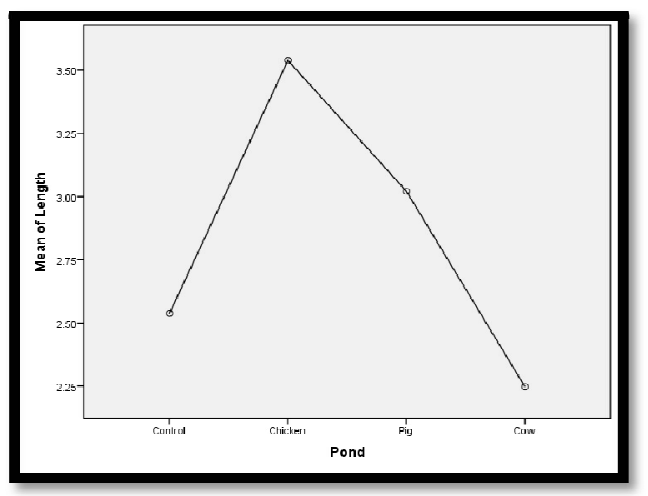

Figure 1: Means Plot

The figure plots the mean figures obtained for each of the manure ponds versus the respective manure pond. The findings show that the chicken manure pond obtained the highest yield, followed by the pig manure pond, while the cow manure pond trailed. An important observation from the plot is that the cow manure pond performed poorly even when compared to the control pond. These findings support the inferences arrived at earlier in as far as ranking of the manure ponds is concerned.

\subsection{Temperature and Ph. Findings}

The experiment also focussed on the collection of temperature and ph. findings for in the treatments as shown by the graphs below. The graph indicates that optimum temperature was 23.5 and the ph. was recorded at 7.5.

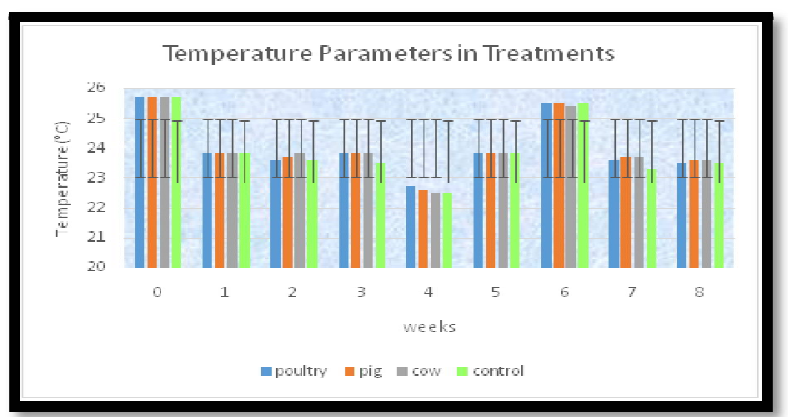

Figure 2: Temperature Parameters Recorded During the Experiment for the Different Treatments

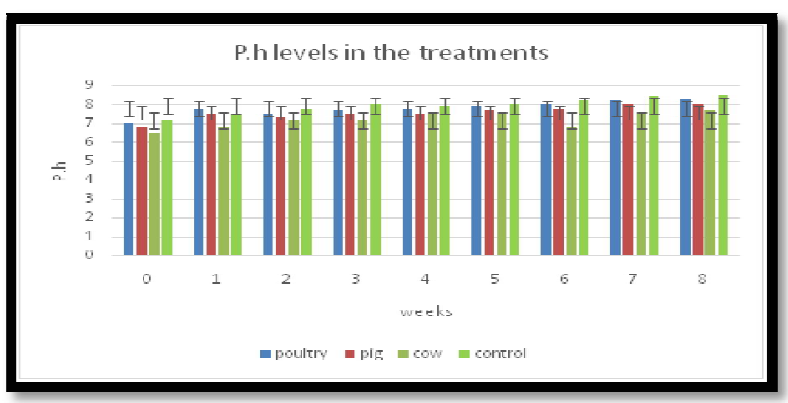

Figure 3: P.H Levels Taken During the Experiment for the Different Treatments

\subsection{Feed Conversion Ratio}

Feed conversion ratio was also calculated using the formula

FCR=Feed given/Animal weight gain (Ngugi et al, 2016) 
And the results were represented graphically as shown in Fig.3.Below.

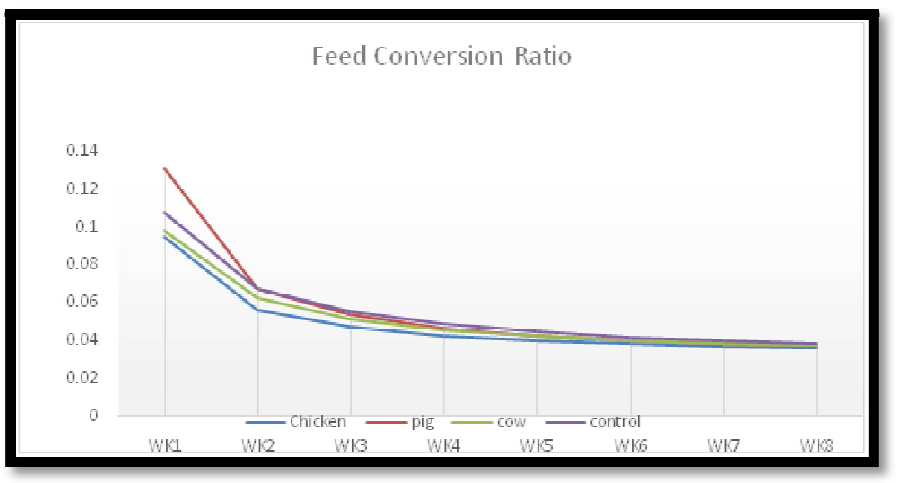

Figure 4: Graph Showing Feed Conversion Ratio of C.Gariepinus for the Different Treatments over Experiment Period

Chicken manure had the best feed conversion ratio followed by pig, control and cow in that order.

The lower the FCR the higher the weight gain obtained from the feed (Hien, et al, 2017)

\subsection{Specific Growth Rate}

Specific growth rates in different ponds were also calculated using the formula

Specific Growth Rate (SGR) = (LnFinal Mean Weight - LnInitial Mean Weight)

(Ngugi et al, 2015)

\section{Length of Feeding Trial (days)}

And the results were as shown in fig.5

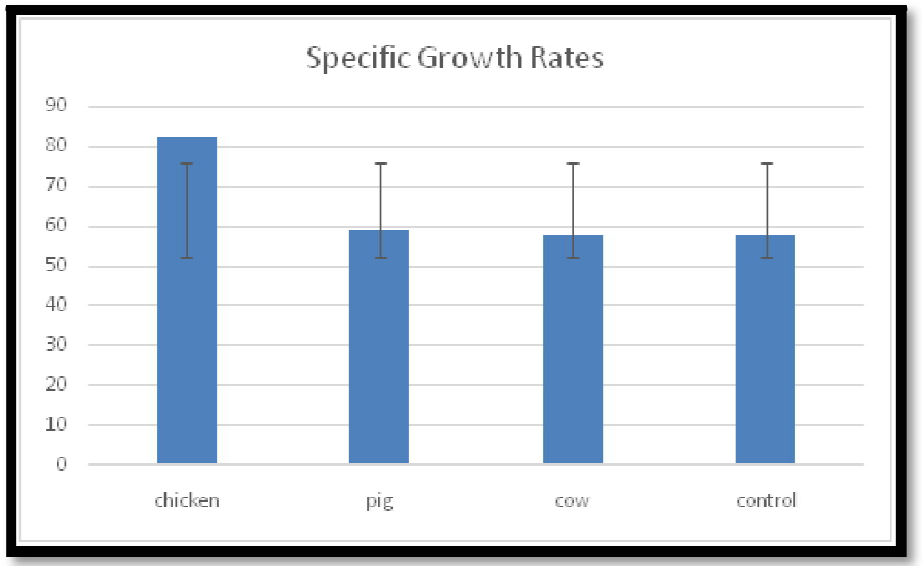

Figure 5: Comparison of Specific Growth Rates of C. Gariepinus Fingerlings Fed by Daphnias from Different Farm Manure in the Treatments

Chicken manure had the best specific growth rate of 82 followed by pig with 59.24, control had 57.91and cow with 57.67 in that order.

\subsection{Survival and Mortality Rates}

Survival and mortality rates were calculated using the formula below

After feeding experiment, the fingerlings were counted to determine the survival and mortality percentage according to the following formula:

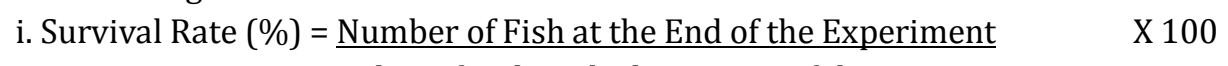

Number of Fish at the beginning of the Experiment

ii. Mortality rate (\%) =Number of Fish that died during the experiment

Number of Fish at the beginning of the Experiment

(Ngugi et al, 2017) 


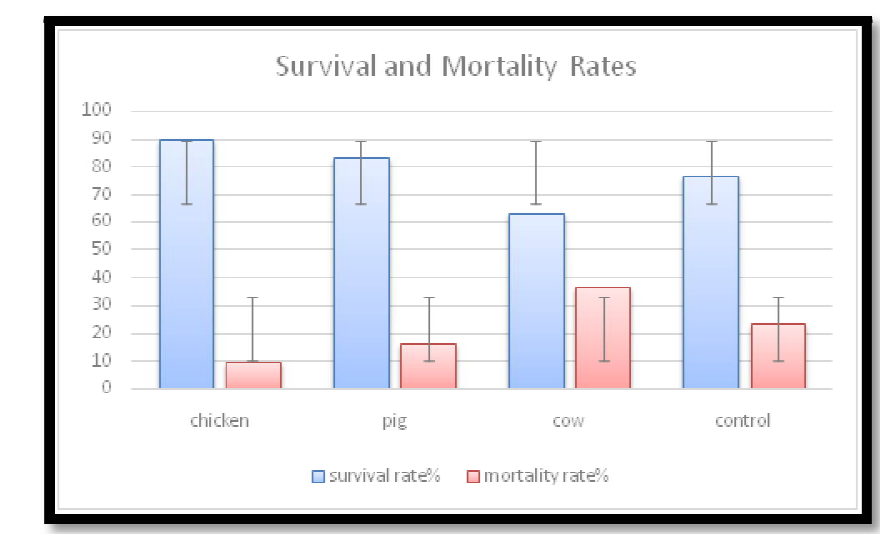

Figure 6: Mortality and Survival Rates of C. Gariepinus during the Experiment Period

From the results above, chicken manure had the highest survival rate with the lowest mortality rate of $90 \%$ and $10 \%$ respectively, followed by pig with $83.3 \%$ survival and $16.7 \%$ mortality, control had $76.7 \%$ survival, $23.3 \%$ mortality, cow had $63.3 \%$ survival and $36.7 \%$ mortality rate.

\section{Discussion}

The findings on weight of the fingerlings under the three types of manure showed that chicken manure pond yielded the best weight increments of Clarius Gariepinus fingerlings. This was supported by the high mean in the descriptive statistics of over 45 while pig manure and cow manure had 34.98 and 33.88 respectively. Moreover, it was supported by the one-way ANOVA post-hoc tests which show the significance level of chicken manure being the least when compared to the other manures at a 5\% level of significance. This analysis of weight shows that chicken manure is the best farm manure, followed by pig manure, while cow manure trails.

Based on the findings of the study it was also clear that the performance of African Catfish (Clarius Gariepinus) Fingerlings fed from water fleas (Daphnia) as live fish feed is only favourable in chicken manure pond and in pig manure pond. This was explained by the fact that performance of these fingerlings was poor and below the performance in the control pond. As a result, it follows that the performance of the fingerlings was extremely poor in cow manure. The study therefore infers that for better performance, the fingerlings can be reared in either chicken or pig manure fed daphnias.

\section{Conclusion and Recommendations}

The nutritive value of daphnia fed from chicken manure is concluded to be highest rating from the performance of fingerlings reared in this pond. For instance, based on the mean figures obtained for length under descriptive statistics, fingerlings in chicken manure had a mean length of 3.53 while pig manure and cow manure yielded 3.02 and 2.24 respectively. Based on this argument, chicken manure yields the highest nutritive value of daphnia based on the performance of fingerlings that feed on them.

Based on the findings of the study, and inferences arrived at, the following recommendations were arrived at.

\subsection{Recommendations}

The study recommends the use of chicken manure to enhance the performance of African Catfish (Clarius Gariepinus) Fingerlings. This is explained by the significantly high performance of fingerlings witnessed among fingerlings reared in chicken manure fed daphnias compared to either pig or cow manure fed daphnias.

Given that cow manure pond turned out to perform worse than the control pond, an in-depth inquest can be done on the same. Such an inquest can aim at determining whether the reason for the poor performance is due to adverse implication on the health and welfare of the fingerlings. Such a study can also seek to determine whether cow manure has any nutritional value on the daphnias fed to fingerlings and/or whether it has components that are harmful to the daphnias.

The study also recommends a similar study with different species of fingerlings. Such a study will facilitate in determining whether the findings holds only for Clarius Gariepinus or they hold also for other fish species.

\section{Acknowledgements}

I acknowledge the provision of experimental site by the Meru County Government, State Department of Livestock and Fisheries and also, I acknowledge technical support and facilities provided by Kenya Methodist University. I thank the lecturers in the faculty of Science and Technology in the later University for their support in writing this journal.

\section{References}

i. Ahmed, N. and J.S. Diana. (2015). Threatening 'White Gold': Impacts of Climate Change on Shrimp Farming in Coastal Bangladesh. Ocean and Coastal Management report \#114:42-52.

ii. Ahmed, N. and J.S. Diana. (2016). Does Climate Change Matter for Freshwater Aquaculture in Bangladesh? Regional Environmental Change report\#16(6):1659-1669. 
iii. Amankwah, A., K.K. Quagrainie, and P.V. Preckel. (2016). Demand for Improved Fish Feed in the Presence of a Subsidy: A Double Hurdle Application in Kenya. Agricultural Economics 47(6):633- 643.

iv. Anane-Taabeah, G., K.K. Quagrainie, and S. Amisah. (2016). Assessment of Farmed Tilapia Value Chain in Ghana. Aquaculture International \#24(4):903-919.

v. Ansah, Y.B. and E.A. Frimpong. (2015). Impact of the Adoption of BMPs on Social Welfare: A Case Study of Commercial Floating Feeds for Pond Culture of Tilapia in Ghana. Cogent Food \& Agriculture \#1(1):1048579.

vi. Ansah, Y.B. and E.A. Frimpong. (2015). Using Model-Based Inference to Select a Predictive Growth Curve for Farmed Tilapia. North American Journal of Aquaculture 77(3), 281-288. https://afspubs.onlinelibrary.wiley.com/doi/10.1080/15222055.2015.1020080

vii. Apraku, A., L. Liu, X. Leng, E.J. Rupia, and C.L. Ayisi. (2017). Evaluation of Blended Virgin Coconut Oil and Fish Oil on Growth Performance and Resistance to Streptococcus in a Challenge of Nile Tilapia (Oreochromis niloticus). Egyptian Journal of Basic and Applied Sciences 4(3):175-184. https://www.sciencedirect.com/science/article/pii/S2314808X17302026

viii. Bengtson, D.A., P. Chheng, T. Puthearath, and N. So. (2015). Aquaculture Carrying Capacity of Stung Chinit Reservoir: A Pilot Project report. Catch and Culture \#21(2): 58-60.

ix. Boyd, C.E. (2015). Efficiency of Mechanical Aeration: Global Aquaculture Advocate.

x. Boyd, C.E. and A. McNevin(2015). Embodied Resource Use in Feed-Based Aquaculture: Global Aquaculture Advocate

xi. Bukenya, J. O. (2017). Assessment of Price Volatility in the Fisheries Sector in Uganda. Journal of Food Distribution Research 48(1):81-88. https://www.researchgate.net/publication/330354861

xii. Bukenya, J.O. and M.B. Ssebisubi. (2015). Price Transmission and Threshold Behavior in the African Catfish Supply Chain in Uganda. Journal of African Business 16(1-2):180-197. https://www.tandfonline.com/doi/abs/10.1080/15228916.2015.1035598

xiii. Chow, M., L.A. Cramer, and H.S. Egna. (2016). Gender Dimensions in Disaster Management: Implications for Coastal Aquaculture and Fishing Communities in the Philippines. In Responses to Disasters and Climate Change: Understanding Vulnerability and Fostering Resilience, in M. Companion and M.S. Chaiken (Eds), Boca Raton, FL: Taylor \&Francis (2nd ed., pp. 159-172).

xiv. Contreras-García, M.J., W.M. Contreras-Sanchez, U. Hernández-Vidal, and A. Mcdonald-Vera. (2015). Induced Spawning of the Common Snook (Centropomus undecimalis) in Captivity Using GnRH-a Implants.

xv. Darko, F.A., K.K. Quagrainie, and S. Chenyambuga. (2016). Consumer Preferences for Farmed Tilapia in Tanzania: A Choice Experiment Analysis. Journal of Applied Aquaculture 28(3):131-143. https://www.tandfonline.com/doi/abs/10.1080/10454438.2016.1169965

xvi. Deck, C.A., J.L. Honeycutt, E. Cheung, H.M. Reynolds, and R.J. Borski. (2017). Assessing the Functional Role of Leptin in Energy Homeostasis and the Stress Response in Vertebrates.

xvii. Douros, J.D., D.A. Baltzegar, J. Mankiewicz, J. Taylor, Y. Yamaguchi, D.T. Lerner, A.P. Seale, E.G. Grau, J.P. Breves, and R.J. Borski. (2017). Control of Leptin by Metabolic State and Its Regulatory Interactions with Pituitary Growth Hormone and Hepatic Growth Hormone Receptors and Insulin like Growth Factors in the Tilapia (Oreochromis mossambicus).

xviii. Engle, C.R., K. Quagrainie, and M.M. Dey. (2016). Seafood and Aquaculture Marketing Handbook (Eds). (2nd ed. Chichester, 468 pp.) , UK: Wiley Blackwell.

xix. Frimpong, E.A. and G. Anane-Taabeah. (2017). Social and Economic Performance of Tilapia Farming in Ghana. In Social and Economic Performance of Tilapia Farming in Africa, J. Cai, K. K. Quagrainie, and N. Hishamunda(Eds, pp. 49-90.)Rome, Italy.

xx. Goodwin, B. and L. Carroll. (2016). Fish Fill Ponds, Plates, and Pocketbooks in Nepal. USAID Feed the Future Newsletter, \# 56.

xxi. Gorospe, K.D., W. Michaels, R. Pomeroy, C. Elvidge, P. Lynch, S. Wongsbusarakum, and R.E. Brainard. (2016). The Mobilization of Science and Technology Fisheries Innovations towards an Ecosystem: Approach to Fisheries Management in the Coral Triangle and Southeast Asia.

xxii. Grimm-Greenblatt, J.R. Pomeroy, B. Bravo-Ureta, L.X. Sinh, H.V. Hien, and T. Getchis. (2015). Economic Analysis of Alternative Snakehead Channa striata Feed: Aquaculture Economics \& Management.

xxiii. Hien, T.T.T., B.M. Tam, T.L.C. Tu, and D.A. Bengtson. (2017). Weaning Methods Using Formulated Feeds for Snakehead (Channa striata and Channa micropeltes) Larvae. Aquaculture Research \#48(9):4774-4782.

xxiv. Hien, T.T.T., B.M. Tam, T.L.C. Tu, and D.A. Bengtson. (2017). Weaning Methods Using Formulated Feeds for Snakehead (Channa striata and Channa micropeltes) Larvae. Aquaculture Research \#48(9):4774-4782.

xxv. Hien, T.T.T., N.H.D. Trung, B.M. Tam, V.M.Q. Chau, N.H. Huy, C.M. Lee, and D.A. Bengtson. (2016). Replacement of Freshwater Small-Size Fish by Formulated Feed in Snakehead (Channa striata) Aquaculture: Experimental and Commercial-Scale Pond Trials, with Economic Analysis. Aquaculture Reports \#4:42-47.

xxvi. Hien, T.T.T., P.M. Duc, T.T.L. Cam, P.T. Minh, T.D.T. Mai, and D.A. Bengtson. (2016). Growth Performance and Immune Response of Snakehead, Channa striata (Bloch 1793) Fed Soy Diets with Supplementation of Mannan Oligosaccharides.

xxvii. Hien, T.T.T., T.D. Dinh, T.M. Phu, and D.A. Bengtson. (2015). Assessment of the Trash-Fish Diet for Snakehead Aquaculture in Vietnam: Species Composition and Chemical Characterisation. 
xxviii. Hien, T.T.T., T.M. Phu, T.L.C. Tu, N.V. Tien, P.M. Duc, and D.A. Bengtson. (2017). Effects of Replacing Fish Meal with Soya Protein Concentrate on Growth, Feed Efficiency and Digestibility in Diets for Snakehead, Channa striata. Aquaculture Research report \#48(6):3174-3181.

xxix. Hien, T.T.T., T.T. Be, C.M. Lee, and D.A. Bengtson. (2015). Development of Formulated Diets for Snakehead (Channa striata and Channa micropeltes): Can Phytase and Taurine Supplementation Increase Use of Soybean Meal to Replace Fish Meal?

xxx. Hyuha, T.S., W. Ekere, H.S. Egna, and J.J. Molnar. (2017). Social and Economic Performance of Tilapia Farming in Uganda. In Social and Economic Performance of Tilapia Farming in Africa, J. Cai, K.K. Quagrainie, and N. Hishamunda(Eds) pp. 127- 144.)Rome, Italy.

xxxi. Li, Y., X. Guo, L. Chen, X. Bai, X. Wei, X. Zhou, S. Huang, and W. Wang. (2015). Inferring Invasion History of Red Swamp Crayfish (Procambarus clarkii) in China from Mitochondrial Control Region and Nuclear Intron Sequences. International Journal of Molecular Sciences 16(7):14623-14639. https://www.ncbi.nlm.nih.gov/pmc/articles/PMC4519862

xxxii. Liu, L. X. Su, T. Chen, K. Li, J. Zhan, H. Egna, and J. Diana. (2015). Evidence of Rapid Transfer and Bioaccumulation of Microcystin-LR Poses Potential Risk to Freshwater Prawn Macrobrachium rosenbergii (de Man). Aquaculture Research \#47(10):3088-3097.

xxxiii. Mandal, R.B., S. Rai, M.K. Shrestha. D.K. Jha, N.P. Pandit, and S.K. Rai. (2016). Water Quality and Red Bloom Algae of Fish Ponds in Three Different Regions of Nepal.

xxxiv. Manyala, J.O., R.S. Pomeroy, P. Nen, K. Fitzsimmons, M.K. Shrestha, and J.S. Diana. (2015). Low-cost tilapia production with fertilization and supplementary feeding.

xxxv. Matuha, M., J. Molnar, C.E. Boyd, and J.S. Terhune. (2016). The Role of Mobile Phones in Facilitating Aquaculture Development in Uganda.

xxxvi. Minoo, C. M., C.C. Ngugi, E. Oyoo-Okoth, A. Muthumbi, D. Sigana, R. Mulwa, and E.J. Chemoiwa. (2016). Monitoring the Effects of Aquaculture Effluents on Benthic Macroinvertebrate Populations and Functional Feeding Responses in a Tropical Highland Headwater Stream (Kenya).

xxxvii. Minoo, C. M., C.C. Ngugi, E. Oyoo-Okoth, A. Muthumbi, D. Sigana, R. Mulwa, and E.J. Chemoiwa. (2016). Monitoring the Effects of Aquaculture Effluents on Benthic Macroinvertebrate Populations and Functional Feeding Responses in a Tropical Highland Headwater Stream (Kenya).

xxxviii. Mugo-Bundi, J., E. Oyoo-Okoth, C.C. Ngugi, D. Manguya-Lusega, J. Rasowo, V. Chepkirui-Boit, M. Opiyo, and J. Njiru. (2015). Utilization of Caridina nilotica (Roux) Meal as a Protein Ingredient in Feeds for Nile Tilapia (Oreochromis niloticus). Aquaculture Research report \#46(2):346-357.

xxxix. Mwanja M, Rutaisire J, Ondhoro CC, Ddungu R, Aruho C. (2015). Current fish Hatchery Fish Practices in Uganda: The Potential for future investment. International Journal of Fisheries and Aquaculture, 2(4):224232.https://fisheriesjournal.com/archives/2015/vol2issue4/PartE/2-4-58.

xl. Naigaga, S., C.E. Boyd, P. Gaillard, and H.A. Abdulrahman. (2017). Assessing the Reliability of Water Test Kits for Use in Pond Aquaculture. Journal of the World Aquaculture Society 48(4):555-562.

https://www.researchgate.net/publication/309143846

xli. Navy, H., T.H. Minh, and R.S. Pomeroy. (2017). Impacts of Climate Change on Snakehead Fish Value Chains in the Lower Mekong Basin of Cambodia and Vietnam. Aquaculture Economics and Management.

xlii. Ndanga, L.Z.B., K.K. Quagrainie, C.C. Ngugi, and J. Amadiva. (2015). Application of Porter's Framework to Assess Aquaculture Value Chain in Kenya. African Journal of Food, Agriculture, Nutrition, and Development 15(3):10118-10137. https://www.ajol.info/index.php/ajfand/article/view/122016

xliii. Ngugi, C.C., B. Nyandat, J.O. Manyala, and B. Wagude. (2017). Social and Economic Performance of Tilapia Farming in Kenya. In Social and Economic Performance of Tilapia Farming in Africa, (Eds) J. Cai, K. K. Quagrainie, and N. Hishamunda. Rome, Italy: FAO Fisheries and Aquaculture, (2nd ed., pp. 91-111).

xliv. Ngugi, C.C., E. Oyoo-Okoth, and M. Muchiri. (2017). Effects of Dietary Levels of Essential Oil (EO) Extract from Bitter Lemon (Citrus limon) Fruit Peels on Growth, Biochemical, HaematoImmunological Parameters and Disease Resistance in Juvenile Labeo victorianus Fingerlings Challenged with Aeromonas hydrop. Aquaculture Research report\#48(5):2253-2265.

xlv. Ngugi, C.C., E. Oyoo-Okoth, J. Mugo-Bundi, P.S. Orina, E.J. Chemoiwa, and P.A. Aloo. (2015). Effects of Dietary Administration of Stinging Nettle (Urtica dioica) on the Growth Performance, Biochemical, Hematological and Immunological Parameters in Juvenile and Adult Victoria Labeo (Labeo victorianus) Challenged with Aeromonas hydrophila.

xlvi. Ngugi, C.C., E. Oyoo-Okoth, J.O. Manyala, K. Fitzsimmons, and A. Kimotho. (2017). Characterization of the Nutritional Quality of Amaranth Leaf Protein Concentrates and Suitability of Fish Meal Replacement in Nile Tilapia Feeds. Aquaculture Reports \#5:62-69.

xlvii. Ngugi, C.C., H.S. Egna, E. Oyoo-Okoth, and J.O. Manyala. (2016). Growth, Yields and Economic Benefit of Nile Tilapia (Oreochromis niloticus) Fed Diets Formulated from Local Ingredients in Cages. International Journal of Fisheries and Aquatic Studies 4(6):191-195.www.fisheriesjournal.com/archives/2016/vol4issue6/...

xlviii. Nguyen, T.N.H., T.T.M. Thu, and T.T.T. Hien. 2016. Quality Enhancement of Dried Snakehead Fish (Channa striata) by Supplementing Wine and Glycerol. Journal of Agriculture and Rural Development 1:74-84. https://aquafishcrsp.oregonstate.edu/aquafish-nop 
xlix. Oo, M. T.A.M. Shahabuddin, D.P. Thakur, A.A. Mon, A. Yakupitiyage, A.N. Bart, R.C Bhujel, and J.S. Diana. (2015). Optimization of Phosphorus Fertilizer in Supplemental Feed-Fed Based Nile Tilapia (Oreochromis niloticus) Ponds. Aquaculture Research report\#46(12):2859-2870.

l. Pandit, N. P., R. Wagle, and R. Ranjan. (2017). Alternative Artificial Incubation System for Intensive Fry Production of Nile Tilapia (Oreochromis niloticus). International Journal of Fisheries and Aquatic Studies 5(4):425-29.https://aquafishcrsp.oregonstate.edu/sites/...

li. Pomeroy, R.S., H. Navy, A.J. Ferrer, and A.H. Purnomo. (2017). Linkages and Trust in the Value Chain for SmallScale Aquaculture in Asia. Journal of the World Aquaculture Society 48(4):542554.https://onlinelibrary.wiley.com/doi/full/10.1111/jwas.12407

lii. So, N., S. Phommakone, L. Vuthy, T. Samphawamana, N.H. Son, M. Khumsri, N.P. Bun, K. Sovanara, P. Degen, and P. Starr. (2015). Economic Value of Lower Mekong Fisheries: Lower Mekong Fisheries Estimated to be wortharound $\$ 17$ billion a year.

liii. Stutzman, E., J.J. Molnar, G. Atukunda, and J.K. Walakira. (2017). Understanding the Role of Fish Farmer Associations as Intermediaries for the Commercialization of Aquaculture in Uganda. Fisheries and Aquaculture Journal 8(3):214. https://www.researchgate.net/publication/319459801.

liv. Thu, T.T.M., T.N.H. Nguyen, and T.T.T. Hien. (2015). A Study of Using Crude Bromelain Enzyme in Producing Salty Fermented Fish Product from Commercial Snakehead Fish. Science and Technology Journal of Agriculture \& Rural Development: Ministry of Agriculture and Rural Development, Vietnam 19:78-85. https://aquafishcrsp.oregonstate.edu/aquafish-nop

lv. Touch, B., N. So, P. Chheng, P. Chhantana, E. Net, and R.S. Pomeroy. (2015). Fish Consumption among Women and Pre-School Children in Cambodia.

lvi. Ward, D., D.A. Bengtson, C.M. Lee, and M. Gomez-Chiarri. (2016). Incorporation of Soybean Products in Summer Flounder (Paralichthys dentatus) Feeds: Effects on Growth and Survival to Bacterial Challenge.

lvii. Won, E.T., J.D. Douros, D. A. Hurt, and R.J. Borski. (2016). Leptin Stimulates Hepatic Growth Hormone Receptor and Insulin-like Growth Factor Gene Expression in a Teleost Fish, the Hybrid Striped Bass. 